\title{
Uma sociologia em ato dos intelectuais: os combates de Karl Kraus I
}

Michael Pollak

\section{Resumo}

A posição que Karl Kraus ocupou no campo intelectual austríaco é única na história dos intelectuais. Em vez de tentar reconstruir seu pensamento como uma teoria, é possível interpretá-lo como um revelador das regras do jogo que caracterizam o campo intelectual. Os escritos de Kraus sugerem muito mais uma releitura no sentido de uma sociologia-ação, que lança mão de técnicas de provocação para tornar visíveis as sanções a que ficam expostos aqueles que atrapalham o jogo combinado de dissimulação das relações entre intelectuais e poder. A análise das intervenções de Kraus possibilita vincular suas lutas a fenômenos de crise do campo intelectual. O papel desempenhado por ele foi o de denunciar as implicações de um processo de racionalização das atividades intelectuais, definido, inicialmente, pela substituição de um mercado intelectual pelo mecenato e, depois, pela extensão e estruturação desse mercado em razão de demandas sociais cada vez mais precisas.

Palavras-chave: Karl Kraus. Intelectuais. Poder. Doxa. Guerra Mundial

\section{O Artigo}

Poucos escritores conseguiram polarizar tanto as opinióes sobre eles quanto Karl Kraus. E náo sem razáo: foram poucos os que, como ele, consagraram tantos escritos críticos a praticamente todos os integrantes do seu círculo. À parte sua considerável obra poética e teatral, os textos satíricos de Kraus são um testemunho bastante completo da vida dos intelectuais

\footnotetext{
1 Publicado originalmente em Actes de la Recherche en Sciences Sociales. vol. 36-37, La représentation politique-1, p. 87-103, février/mars, 1981. Tradução de Letícia Borges Nedel.

2 Michael Pollak foi pesquisador do CNRS e membro do Grupo de Sociologia Política e Moral e do Instituto de História do Tempo Presente. Publicou, entre outros: Vienne 1900 (1984), Les Homosexuels et le sida: sociologie d'une épidémie (1988), L'Expérience concentrationnaire, Essai sur le maintien de l'identité sociale (1990).
}

\section{$((c))$ Br}

Direito autoral e licença de uso: Este artigo está licenciado sob uma Licença Creative Commons. Com essa licença você pode compartilhar, adaptar, para qualquer fim, desde que atribua a autoria da obra, forneça um link para a licença, e indicar se foram feitas alterações. 
austríacos de seu tempo. Mesmo os escritos poéticos e as peças de teatro frequentemente trazem à cena casos típicos desse meio.

A posição ocupada por Karl Kraus no campo intelectual austríaco é única na história dos intelectuais. Tendo redigido praticamente sozinho uma revista de humor por quase 40 anos, suas tomadas de posiçáo sobre os mais diversos assuntos eram percebidas por seu público mais fiel como uma palavra de verdade acima de qualquer suspeita. E apesar do silêncio oficial dos jornais da época em relação a eles, os artigos publicados na Die Fackel (A Tocha) alimentavam o debate público. Pode-se dizer sem exagero que Kraus foi, durante muitas décadas, uma instituição na vida intelectual vienense.

Por todo um período a Fackel dominou a vida intelectual vienense. Quem ela vai atacar amanhã? Essa era a pergunta que permanentemente se fazia. A Fackel fazia parte da vida na cidade. Gente que até então nunca tinha comprado uma folha impressa se informava lendo a Fackel. Os jovens reservavam tempo para a Fackel como para suas idas ao cinema, como se fossem ao teatro (SCHEU, 1909, p. 6-7).

Não surpreende que um personagem assim carismático, para não dizer mítico, tenha gerado um dilúvio de comentários e interpretaçóes. Já de saída a literatura sobre Kraus se apresenta como tentativa de reconstruir uma "doutrina" - seja literária, seja política. É como se a reflexão sobre um personagem de tamanha influência no meio intelectual não pudesse passar sem a análise do seu "pensamento" ou da sua "teoria". Assim, para contradizer seu "elitismo cultural", análises críticas interpretam sua defesa da pureza linguística e literária como uma teoria que, sociologicamente falando, seria o resultado da situação privilegiada de rentista e da consequente inaptidão para reconhecer a sobredeterminação da vida intelectual de seu tempo pelo capital financeiro emergente ${ }^{3}$. Outras análises, debruçadas sobre o pensamento e as escolhas por vezes ambíguas de Kraus, caracterizam sua doutrina política como sendo originária do humanismo pacifista e do liberalismo intelectual burguês, ambos incapazes de reconhecer a necessidade de disciplina do intelectual em face de uma organização política progressista ${ }^{4}$. Parece que os comentadores atuais, tal como faziam

3 Ver, sobretudo, a tese de BÄHR (1977). Desde a Primeira Guerra Mundial e a cada vez que Kraus entrava em conflito aberto com intelectuais ligados às organizações de esquerda, esse argumento aparecia. Ver também SCHICK (1995, p. 10).

4 Para uma análise da relação de Karl Kraus com a social-democracia, ver PFABIGAN (1976). Ver ainda o juízo expresso por FISCHER (1969, p. 154 ss). 
os contemporâneos dele, sentem necessidade de justificar suas próprias escolhas e compromissos frente a uma instância outra, percebida acima de tudo como instância moral. No entanto, reconstituir, como faz a maior parte dos analistas, uma doutrina ou uma espécie de teoria geral a partir dos artigos publicados na Fackel revela-se um empreendimento impossível e fadado ao fracasso. Mesmo lá no único domínio onde Kraus fez uma tentativa explícita de teorização, o domínio da língua, logo nos deparamos com as dificuldades decorrentes do caráter rudimentar e, finalmente, pouco sistemático desse corpus. O que sobra dessas reconstituiçóes teóricas é a constatação de retorno à pureza, a uma visão realista e um estilo despojado que situam Karl Kraus ao lado de outros personagens que, na virada do século, tentaram romper com as formas intelectuais e artísticas dominantes: Adolf Loos, na arquitetura, Arnol Schonberg, na música; Oskar Kokoschka, na pintura.

Em vez de tentar reconstruir o pensamento de Kraus como uma teoria, podemos nos aproximar dele como um revelador das regras do jogo que caracterizam o campo intelectual. Até porque, o uso de nomes próprios, a polêmica pessoal, o tom geralmente moralizador, todos esses elementos de estilo indicam não se tratar um intelectual teórico. Os escritos de Kraus sugerem muito mais uma releitura no sentido da sociologia-ação, que ousa romper com as regras de cortesia e lançar mão de técnicas de provocação para tornar visíveis as sançóes a que ficam expostos aqueles que atrapalham o jogo combinado de dissimulação das relações entre intelectuais e poder. Por isso, a grande quantidade de processos movidos por ele e contra ele é indissociável dos textos que produziu, no que lhe servem de meio de demonstração e verificação de seus argumentos.

De outra parte, fazendo reproduzir na Fackel tudo o que os contemporâneos vinham publicando a respeito de si e de suas obras na imprensa estrangeira e austríaca, Kraus pretendeu desvelar as redes e relaçóes de oposição e coalisão que atravessam o meio literário e intelectual, e que estruturam os seus mecanismos de difusão. Vale lembrar, nesse ponto, do ostracismo que se abateu sobre ele e de todos os pequenos atos de discriminação que aos olhos dos admiradores eram um sinal da boa fundamentação das suas lutas. A imprensa austríaca orquestrou contra Kraus uma campanha 
difamatória, seguida da mais completa indiferença - duas táticas opostas, mas com a mesma intenção de reduzi-lo ao silêncio. Veremos que esse papel de inconfidente que ele desempenha para pôr a doxa do campo a nu alcança maior eficácia justo nos momentos em que se reservou ao silêncio, durante a Primeira Guerra Mundial e durante a tomada do poder nazi. A crítica exercida por esse silêncio sobre os que continuam a falar e a publicar é, enquanto julgamento moral, ainda mais pesada do que as mais ácidas polêmicas.

Kraus deveu sua reputação de grande intelectual menos a uma mensagem dirigida ao exterior, guiada pela intenção de influenciar os rumos da evolução política e social, do que ao efeito extraordinário exercido por ela nos conflitos entre intelectuais. Vivendo as contradiçóes intelectuais ao extremo, ele se voltou principalmente à crítica interna do seu meio social.

Neste artigo pretende-se ressaltar, nas ações e textos de Kraus, os aspectos que fazem dele um sociólogo dos intelectuais. Trata-se de explicitar o sentido das suas intervençóes, sempre marcadas por uma encenação meticulosa, e que, numa linguagem moderna, poderiam ser qualificadas como "happenings". A apresentação de algumas dessas intervenções será articulada a uma retomada (necessariamente esparsa) de elementos da sua biografia e da sua trajetória, que contribuíram para fazê-lo ingressar nessa espécie de sociologia-ação.

\section{A trajetória social de um purista da escrita}

Tudo na juventude e no começo da carreira de Karl Kraus o predestinava a tornar-se a figura que mais tarde elegeria como alvo predileto: um literato-jornalista dos cafés vienenses. Nascido em 1874 em Jicin (norte da Boêmia), nono e último filho de um fabricante de artigos de papel, Karl Kraus passou a infância durante os anos cruciais das tentativas de reorganização interna do Império em grande segurança material. Depois da derrota contra a Prússia em 1866, da divisão do Império em uma parte húngara e outra austríaca, de um período de crescimento econômico e liberalismo político que viria a desembocar na grande crise de 1873, com a falência de vários bancos e a queda dos índices da bolsa, a Áustria conheceu um período de contínuas discussóes sobre a reestruturação do Estado. $\mathrm{Na}$ maior parte das vezes, essas tentativas de reforma não ultrapassavam o estágio da 
discussão e acabavam abortadas depois de serem entremeadas aos conflitos crescentes entre as nacionalidades. Por trás de uma fachada de refinamento artístico e estilos de vida sofisticados, o Império havia se transformado num "laboratório de pesquisa da destruição do mundo" 5 .

Economicamente, o industrial e comerciante Jakob Kraus sobrevivera bem à crise de 1873. Depois de começar com uma pequena fábrica de artigos de papel, ele alcançou o quase monopólio do mercado de sacolas na Europa Central, complementado pela representação exclusiva de uma marca de tinta para caneta. Em 1877, a família muda-se para Viena, nova sede da empresa, que também possuía uma filial em Praga. A escolha do domicílio vienense recai sobre um bairro onde tendiam a se instalar famílias prósperas, mas sem condiçóes de pretender laços diretos com o poder. Situado na periferia do centro da cidade e bem perto da Ringstrasse, ele ficava próximo das novas moradias da burguesia liberal. ${ }^{6} \mathrm{O}$ lugar de residência exprime bem a posição da família de Kraus na estrutura social do Império: uma burguesia judia ascendente, assimilada à cultura alemá, que por essa época chegava a Viena vinda das províncias eslavas do norte e do leste.

A análise da trajetória literária de Karl Kraus deve levar em conta uma mudança ocorrida na burguesia liberal austríaca. Depois de anos de exercício do poder político, e sob pressão simultânea da aristocracia e dos novos movimentos de massa (social-cristão, pangermanista e social-democrata), a burguesia viu-se mais uma vez obrigada a ceder lugar para a aristocracia, que entáo figurava como a única força capaz de defender a unidade da monarquia ameaçada pelos conflitos nacionais, os quais também atravessavam a própria burguesia (SCHORSKE, 1980, p. 303 ss). Essa contingência bloqueou a recém-iniciada democratização da vida política na parte austríaca do Império.

Até então o governo vinha praticando uma política de promoção da expansão industrial e de subvenção da vida artística e cultural, movida pela intenção de obter o apoio da burguesia aos seus esforços por manter

\footnotetext{
5 É o título de um capítulo do liuro de FIELD (1967, p. 32).

6 Para uma análise acurada da geografia social dos bairros do centro de Viena à época das reformas urbanas, ver SCHORSKE (1980, p. 24 ss).
} 
os movimentos de massa sob controle. No domínio da pintura e da arquitetura, via de regra, favoreceu a vanguarda modernista de Viena - a exemplo do arquiteto Otto Wagner, responsável por grande número de prédios públicos, como o centro de triagem dos correios e as estaçóes do sistema de trens urbanos (Stadbahn) - ou os pintores do grupo Sécession reunidos em torno de Gustav Klimt, para quem se abriram novos mercados no âmbito estatal, não só nos museus, mas também, por exemplo, o desenho dos selos de correio. Se por um lado a estratégia de buscar a adesão dos intelectuais e artistas ao regime ajudou a criar as condiçóes para o florescimento da lendária "Viena 1900", essa política restava controversa quanto a ter contribuído também para ocultar, por trás da máscara de uma cultura moderna e universalista, as alteridades nacionais do Império, assim como a incapacidade dos sucessivos governos de procederem às necessárias reformas políticas ${ }^{7}$.

Em tais condiçóes, a força economicamente dominante via-se condenada a desempenhar o papel de um "anão político" - limitação da qual se ressentia fortemente a burguesia judia, que mantida marginal dentro de sua própria classe, temia com justa razáo que a exclusão da burguesia liberal do poder reduzisse significativamente as chances de sucesso das suas aspiraçôes à assimilação. E com efeito assiste-se, por essa época, ao fortalecimento do anti-semitismo tradicional, de inspiração religiosa no movimento social-cristão, e de inspiração racial no movimento pangermânico de Georg von Schönerer. Nesse contexto, o recolhimento à ciência, à arte e à literatura se oferecia como saída aos filhos de uma classe economicamente dominante, mas politicamente impotente.

Karl Kraus era uma criança de saúde frágil e concentrada nos estudos, um aluno-modelo. $\mathrm{O}$ que a escola mais lhe acrescentou de importante foi o amor pela literatura e o teatro. Já desde os últimos anos do liceu ele frequentava os cafés literários, sobretudo o café Griensteidl, onde fez amizade com Hugo von Hofmannsthal, com quem festejaria a saída da escola depois do exame baccalauréat ${ }^{8}$. Seguindo o desejo do pai, matriculou-se em Direito, mas não seguiu curso algum: passava a vida no café Griensteidl,

7 Ver a análise da Sécession e da política cultural governamental em SCHORSKE (1980, p. 236 sS).

8 N.T. Título de bacharel conferido depois de aprovação em exame realizado ao final do respectivo Ensino Médio. 
onde encontrava Arthur Schnitzler e Hermann Bahr, a cabeça da literatura "moderna" austríaca da época. Por esse tempo, Kraus hesita entre a carreira literária e a de ator, mas depois de uma representação desastrosa, rapidamente abandona a ideia de se tornar ator para se concentrar na escrita. Escrever na Viena do final do século XIX era quase sinônimo de escrever para um jornal ou uma revista.

Nessa atmosfera de devotamento às atividades culturais, a imprensa se desenvolvia. Pela primeira vez na história do jornalismo austríaco, o jornalista assalariado, sob contrato exclusivo de um jornal, vinha substituir o jornalista-escritor freelance. Mas a imprensa que oferecia um mercado privilegiado a uma geração de filhos de burgueses decepcionados e insatisfeitos com sua posição social era também uma empresa claramente subordinada às leis do mercado e do lucro. August Zang, fundador do jornal A Imprensa, costumava vangloriar-se de nunca ter publicado uma só linha que não tivesse sido paga. Chamava seu jornal de "revista que vende publicidade" (BAHR, 1977, p. 26). Durante o ano da crise de 1873, o Anglobank chegou a oferecer "uma gratificação" a 73 jornais vienenses. As sociedades anônimas doavam açóes aos proprietários de jornal para constrangê-los a transmitir informaçóes favoráveis em assuntos que fossem do interesse delas. No fundo, a maior parte dos artigos publicados, mesmo nos mais prestigiosos jornais liberais da época, como a Neue Freie Presse e a Presse, era matéria paga.

Por volta do final do século XIX, praticamente todos os jornais vienenses já tinham se tornado propriedade de algum banco (KOHN, 1966, p. 6): o Anglo-Österreichische Bank detinha a Neue Freie Presse, o Wierner Bankverein, a Presse etc. É de supor que o conteúdo das informaçóes econômicas e políticas fosse fortemente predeterminando e, por consequência, o talento jornalístico investisse no estilo, ocupando-se mais de cultura do que de política.

Os jornalistas de então não tinham como deixar de assumir certo distanciamento em relação à dominação exercida sobre seu trabalho. Se a revolta só levava à exclusão e ao isolamento social, restava-lhes o estilo de vida um pouco cínico e esteta. O clima dos cafés bem o testemunha: "Os cafés vienenses dessa época não eram o ponto de partida de ações políticas, 
mas o ponto de encontro de indivíduos que compartilhavam uma certa solidão e melancolia." (BAHR, 1977, p. 2).

Em tal ambiente floresceu uma espécie muito particular de literatura, o "feuilleton». ${ }^{9}$ Nessa pequena obra-prima de estilo, o conteúdo informativo do texto praticamente não importava mais. A partir de fatos anódinos e cenas insignificantes da crônica social, os feuilletonistes tentavam enriquecer o senso comum com imagens filosóficas "profundas", tudo recoberto por um estilo "brilhante". A mistura de ensaio literário e colunismo mundano-sensacionalista era uma característica dos jornais da época. $\mathrm{O}$ gênero leve, veiculando banalidades, mas sem abandonar a pretensão à plenitude semântica da obra de arte, produzia a adesão e o aplauso dos leitores, contentes de poderem concordar com um "ponto de vista" que, em outras palavras, estava "bem dito". O editorial e os feuilletons eram confiados aos jornalistas e escritores mais conhecidos, e muitos leitores só compravam jornal para ler seu colunista preferido.

No começo, Karl Kraus exercia magistralmente essa literatura de gazetilha "em cartas de verão" que ele escrevia desde Ischl, instância de vilegiatura da família imperial e da boa sociedade vienense com toda a sua camarilha de esnobes e meio-mundanos, uma espécie de Saint-Tropez ou de Cannes austríaca. Na sequência da publicação daquelas cartas, as quais geralmente se revestiam de um humor mordaz, a revista Le Rendez-vous oferece a ele uma coluna fixa. Kraus escreve para jornais vienenses e também publica críticas literárias e peças teatrais em jornais de Berlim, Breslau, Hamburgo e Bremen.

Durante os anos de 1890 , ele vive a contradição dos que aspiram a uma posição e ao mesmo tempo detestam os compromissos que tal posição implica. Logo toma consciência das regras do meio. Como na política, onde a retórica ritual disfarça a incapacidade de resolver os problemas mais prementes, a arte e, sobretudo, a escrita tinham se tornado uma decoração pesada atrás da qual a burguesia escondia a sua impotência. Ainda ao tempo em que almejava um lugar de articulista no jornal vienense mais prestigiado da época, a Neue Freie Presse, Kraus começa a denunciar os

9 N.T. Folhetim de variedades do qual germinou a crônica jornalistica, gazetilha. 
"falsos", os "pretensiosos" e a "frivolidade pesada" da literatura da virada do século. Ataca a substituição das peças clássicas no repertório dos grandes teatros por peças de bulevar francês, defende o novo teatro naturalista de Gerhard Hauptmann, que leva a crítica social à cena, assim como a intenção dos primeiros poetas expressionistas, como Georg Trakl ou Else Lasker-Schüler, de reproduzir honestamente as emoçôes, sem fazer concessóes à forma. Fora do campo literário, Kraus nutre amizade com todos os que também lutavam contra o estilo pomposo e sobrecarregado do final do século, tão bem ilustrado pelos prédios da Ringstrasse, representativos de todos os "neo" imagináveis estilos e interiores Mackart. Entre seus amigos estavam Adolf Loos, para quem a arquitetura vienense havia sucumbido ao espírito Potemkin, o compositor Arnold Shönberg, que revolucionava a concepçáo de harmonia, e o pintor Oskar Kokschka, que acabava de romper com o modernismo da Sécession reunido em torno de Gustav Klimt, entáo em via de se tornar um estilo puramente decorativo, quase oficial do Império ${ }^{10}$.

Duas citações, uma extraída de uma carta escrita em 1893 a Arthur Schnitzler, outra de um artigo publicado anos mais tarde na Fackel, ilustram bem as contradiçóes vividas por Karl Kraus nesse período. Reagindo ao ambiente dos cafés literários, ele escreve: "Detesto e desde sempre detestei essa falsa 'decadência' que não pára de coquetear a si mesma. Luto e vou sempre lutar contra essa poesia maneirista, malsã, masturbatória”. ${ }^{11}$ Em um artigo publicado pouco mais tarde na Fackel, ele descreve seu desejo de suceder ao colunista vedete da Neue Freie Presse, falecido em 1893:

Entre a idade de dezenove e vinte e três anos eu tinha lá as minhas relações. Passei meus anos de juventude a entretê-las e respeitar as regras de cortesia vigentes no meio liberal do jornalismo. Não nego que um lugar de cronista na Neue Freie Pressa atraía o recém-chegado que eu era, obcecado pela escrita e politicamente ingênuo. Entre todos os jornais, esse foi o que me enganou com o torneado de um estilo elevado, que logo aprendi a decifrar... (DIE FACKEL, 1899, p. 5-6).

10 Ver os artigos de Krauss contra essa política e contra Klimt nos números da Die Fackel, 29, p. I6 ss, 1900, e 48, p. 7 ss, 1900, bem como a análise da política cultural governamental por K. Hauer, Die Fackel, 250, p. II ss, 1908.

II Carta a Arthur Schnitzler, março de 1893, citada em SHICK (1985, p. 29). 
Sua primeira grande sátira "sobre literatos modernos de botequim" neuróticos e decadentes" é A Literatura Demolida, publicada em 1897 por ocasião da demolição do imóvel que abrigava o café Griensteidl (KRAUS, 1897). Nela Kraus denuncia o estilo e a atmosfera dos escritores que se comprazem com a própria decadência; rejeita a sua afetação e pieguice; também acusa a associação entre a arte e o comércio que a imagem de esoterismo transmitida por esse tipo de artista dissimula.

Por trás dos pseudônimos era possível identificar todos os habitués do café naquele panfleto, e se o sucesso dele atesta a grande força de digestão do meio, um incidente marca o ponto a que os golpes de Kraus haviam chegado: seu antigo amigo Felix Salten o agride fisicamente em plena rua. Salten, um pouco mais velho que Kraus, compartilhava com ele a obsessão de vencer na carreira literária. Mas enquanto Kraus, ainda na situação de aspirante, já manifestava sua revolta contra o círculo literário dominante, Salten estava disposto a se corromper para vencer.

No limite, tudo o que Kraus escreveu naqueles anos pode ser lido como expressáo de uma vontade deliberada de se separar daqueles a quem permanecia ligado por suas ambiçóes profissionais, como se tivesse necessidade de fechar as portas que se abriam para ele, como se quisesse complicar, quando não impedir, os favores que seus amigos se dispunham a lhe prestar. Kraus fazia de tudo para se tornar um "fora da lei" do meio literário, aquele que ultraja a benevolência e a polidez cortesã, para-vento chinês a encobrir as ligaçóes da escrita com a comercialização. Assim é como ele se apresenta no editorial do primeiro número de sua revista Die Fackel, criada em 1899.

Preparado desde longa data (Kraus dedicara um ano inteiro a ele), o número de estreia fez um sucesso espetacular. Os primeiros anos da revista foram integralmente consagrados à luta contra a corrupçáo, a começar pelos corruptos do mundo literário e do espetáculo. Convicto do poder da palavra franca e direta, Kraus dirigia todos os seus ataques ad personam. Para ele, a denúncia da corrupção em termos genéricos e o ataque exclusivo ao "sistema social", considerado como responsável por todos os

12 N.T. No original, "littérateurs modernes de café, décadents et névrotiques». 
males, eram meios cômodos de não dar nome aos bois. Com efeito, seus ataques pessoais incomodavam e eram percebidos como cada vez mais perigosos, a tal ponto que, pouco mais de um mês depois da aparição da Fackel, os críticos de teatro (os primeiros visados pela sua pena), combinaram com um antigo escritor, tido como louco, e que, portanto, não podia ser juridicamente responsabilizado por seus atos, de maltratar Kraus na presença deles. Naquela altura, a Neue Freie Presse, que um ano antes tentara se proteger das críticas oferecendo a Kraus um emprego, escreveu: "O senhor Kraus deverá mudar sua forma de escrever caso pretenda sobreviver ao primeiro quarto de ano de sua Fackel'. ${ }^{13}$

Kraus e sua revista sobreviveram; o que mudou foi a atitude da imprensa. Depois de alguns meses de polêmicas, da criação de revistas concorrentes, todas efêmeras, e da encenaçáo de uma peça de teatro composta para ridicularizá-lo, tornou-se cada vez mais claro que campanhas orquestradas não conseguiriam prejudicá-lo. A grande imprensa opta então por outro modo de "assassinar" um intelectual ou sua obra: não falar dele, o silêncio completo - raramente rompido pelos jornais austríacos durante a vida de Kraus, à única exceçáo da imprensa social-democrata.

Kraus devia o sucesso da revista ao seu estilo meticuloso de trabalho. Toda revelação, apresentada sem nenhuma precaução retórica, só era publicada depois de um controle exaustivo das fontes. Uma vez que as besteiras contidas na fraseologia e na retórica eram o alvo número um das suas investidas, ele se utilizava amplamente da técnica das citaçóes, contentando-se geralmente com breves comentários destinados a revelar as contradiçóes e o ridículo de algum texto. Kraus corrigia sempre pessoalmente todas as provas, para que nenhum erro escapasse no produto final. Fazia com que sua capacidade de trabalho refletisse o seu senso de responsabilidade para com a letra impressa: "Já aconteceu com freqüência de fazer parar as máquinas de impressão e destruir um texto que a balança em miligramas da minha sensibilidade estilística tinha recusado... Só termino um trabalho passando para outro; minhas correçóes de autor tomam todo esse tempo". ${ }^{14}$

13 Artigo reproduzido por K. Krauss em Die Fackel, 9, p. 27, 1899.

14 Ver: KRAUS (1955, p. 133). Ver também: FIELD (1967, p. 13). 


\section{A impossível crítica intelectual e artística}

Uma das primeiras vítimas da intervenção de sociologia-ação de Kraus foi Hermann Bahr, personagem-chave e centro de poder da vida literária na Viena do início do século XX. Bahr personificava o literato-jornalista empreendedor por excelência, homem que monopolizava a crítica literária e teatral da cidade graças à autoridade de sua palavra, mas também graças a sua influência pessoal junto às direçôes de jornais, casas de edição e de teatros. Muitas carreiras começaram com a sua ajuda, outras tantas tinham sido destruídas por algumas linhas suas. Ele podia, em suma, determinar o sucesso ou derrota de uma peça de teatro.

Foi a crítica extremamente negativa que Bahr fez de Gerhard Haptmann o motivo do primeiro ataque de Kraus em 1893, em seu polêmico ensaio Zur Überwindung des Hermann Bahr (Como superar Hermann Bahr). Nele, Kraus atacava menos o estilo literário de Bahr do que o tipo de escritor que ele representa: o servo de quem se dispusesse a pagá-lo, o fabricante de qualquer produto passível de circular no mercado da literatura. $\mathrm{O}$ ataque foi tão violento que mesmo amigos escritores de Kraus que concordavam com seu julgamento - caso, por exemplo, de Detlev von Liliencron -, aconselharam-no a moderar o tom ${ }^{15}$.

Nos ataques posteriores da Fackel, Kraus tentaria demonstrar que Bahr simbolizava um fenômeno situado na origem do declínio do teatro vienense: a sobreposição das funções de crítico e autor de peças teatrais. Esse acúmulo de funçóes teoricamente incompatíveis mostrava o quanto os costumes jornalísticos estavam ligados aos interesses de promoção (geralmente de autopromoção) cultural. A regra do toma lá, dá cá tornava impossível qualquer crítica de arte séria, resultando daí a esclerose do teatro e o continuísmo tradicionalista. Nesse cenário, só muito raramente um diretor teria coragem de recusar as peças, mesmo medíocres, de um jornalista poderoso.

Hermann Bahr, o crítico mais conceituado da época, tinha por princípio escrever críticas positivas sobre todas as peças encenadas nos teatros que também aceitassem encenar peças suas, e demolir todas as peças encenadas

15 Carta de Detlev von Liliencron a Kraus, de 4 de agosto de 1893. 
em outros teatros. Depois de ter-se tornado "autor da casa" de um determinado teatro, ele não hesitava em transformar antigas críticas desfavoráveis em julgamentos positivos, reunidos em alguma coletânea sua. Bahr e o diretor do seu teatro ignoraram os ataques de Kraus tanto quanto possível, até o dia em que este acusou o diretor de haver comprado a benevolência de Bahr com a doação de um terreno, levando-os a prestar queixa contra Krauss, que se esforçava por transformar o processo numa demonstração geral da incompatibilidade entre os papeis de autor e crítico de teatro. Pela primeira vez, Kraus recorre a uma técnica de sociologia-ação: empurrar os adversários para uma situação limite da qual, se quisessem evitar a incriminação, não havia outra saída senão o recurso aos tribunais.

$\mathrm{Na}$ busca de alguma expertise no assunto junto a escritores conhecidos, ele deve ter se dado conta da coragem bastante limitada dos intelectuais. A maior decepção veio de Maximilian Harden, escritor alemão humorista como Kraus, que o tinha encorajado a fundar a Fackel. Privadamente, Harden expressara a sua hostilidade contra Bahr, mas no momento do processo recusou-se a tomar posição. No desenrolar da ação, o juiz aceitou um contrato de venda assinado posteriormente à transaçáo como prova de que as reprovaçóes formuladas por Kraus eram injustificadas, e o condenou. Da mesma forma, o magistrado se recusou a discutir o problema de fundo colocado por Kraus por não considerá-lo diretamente ligado ao objeto da ação processual. ${ }^{16}$ Apesar dessa derrota jurídica, Kraus logo viria a desenvolver a técnica de utilizar os processos quase como uma experiência de laboratório.

Durante os primeiros anos da Fackel, ele lutou em todas as frentes. A análise da imprensa e do jornalismo fez voltar seu interesse, sobretudo, para as matérias sobre "faits divers" e a seção policial onde se noticiavam os crimes morais, ilustração de um gosto doentio pelo sensacional. Segundo ele, o liberalismo que sujeitava a imprensa ao jogo do livre mercado incitava-a a explorar, na apresentação dos fatos, a curiosidade dos leitores nascida da dupla moral e da hipocrisia.

Os ensaios e artigos reunidos em 1908 num livro intitulado Sittlichkeit un Kriminalität (Moral e Criminalidade) são simultaneamente um ataque

16 Para uma descrição detalhada do processo, ver: Kohn (1966, p. 57 ss). 
ao jornalismo e à legislação dos costumes. ${ }^{17} \mathrm{Na}$ verdade, Kraus nunca deixou de lutar contra a destruição das relações de intimidade operada pelo código penal. A audácia de que dão mostra os seus escritos do início do século é atestada por uma carta de Sigmund Freud, na qual o psicanalista o encoraja a continuar sua luta, ${ }^{18}$ e pelo fato de as leis do Código Penal (sobre aborto, adultério, homossexualidade, prostituição) que atacava só terem sido reformadas a partir dos anos de 1970.

Às vésperas da Primeira Guerra Mundial, Kraus continua a aprofundar suas análises, chegando a uma visão bastante pessimista do mundo. A essa altura ele percebe que a sátira aplicada a acontecimentos pontuais não tem o poder de mudar o curso das coisas. Ainda assim, segue acreditando na força da palavra e na imputabilidade da palavra em falso, produto do oportunismo de todo um meio que deveria, ao contrário, ter por vocação resistir às transformaçóes que desde 1910 já se anunciavam nefastas. Ao se acomodarem às oportunidades oferecidas por um mercado cultural controlado pelos grupos econômicos e políticos dominantes, os intelectuais não teriam feito mais do que acelerar e aumentar as forças que conduziam à guerra, previsível desde as guerras dos Bálcás em 1912-1913. Para Kraus, lutar contra esse oportunismo era, em princípio, lutar contra a manipulação da língua.

No limiar da guerra, e para manifestar sua última esperança antes do apocalipse cuja aproximação pressentia, Kraus se abstém progressivamente de toda tomada de posiçáo política, pensando que somente uma renovação espiritual ainda poderia salvar o mundo da catástrofe. Nos novos movimentos políticos de massa (social-cristão, pangermânico e socialista) ele via, sobretudo, a coincidência do ódio com a demagogia. Diante das exacerbaçóes nacionalistas desencadeadas no Império, a fé que a social-democracia depositava nas virtudes do povo parecia-lhe uma fantasia idealizadora. ${ }^{19}$ Uma eventual influência exercida por pessoas incorruptíveis e

17 Uma edição contemporânea desses artigos aparecidos entre 1902 e 1907 pode ser vista em KRAUS (1963).

18 Carta de Sigmund Freud a Kraus, 18 de novembro de 1906.

19 Ilustrativa a esse respeito é a polêmica travada em 1910 com Robert Scheu sobre o sufrágio universal. O Partido Social-Democrata esperava que o sufrágio trouxesse a solução quase automática dos problemas vitais da Monarquia e, de imediato, o das nacionalidades. Scheu defendia o sufrágio universal supondo que somente ele poderia fracionar o Império, em um primeiro momento, para depois, num segundo momento, permitir uma 
com uma visão justa das coisas constituía, para Kraus, uma esperança, por mínima que fosse. Daí sua predileção, que tantas reprovações suscitou, pelos contatos com aristocratas, de onde procedia sua amizade e apoio a Heinrich Lammasch. Professor de direito internacional e representante conservador no parlamento austríaco, este era também um pacifista convicto, que agira com todas as forças contra a guerra, mas que depois de ser excluído das responsabilidades políticas no decurso dela acabou nomeado primeiro ministro alguns dias antes do armistício, apenas para preparar a liquidação do Império e a transição para a paz. Daí também esse ato quase incompreensível e pouco compreendido que é a conversão de Kraus à fé católica em 1911, tendo Adolf Loos por padrinho. O gesto foi interpretado como soluçáo de uma contradição devida à origem judia de Kraus, contradição que lhe fora atribuída porque a imprensa que ele preferencialmente atacava, a grande imprensa liberal dominante da época, era propriedade quase exclusiva de judeus, e geralmente empregava uma alta proporção de jornalistas judeus. Mas a data do batismo, bem posterior a dos ataques mais fortes de Kraus, e também a dos textos em que ele por diversas vezes denunciou a acusação de anti-semitismo frequentemente endereçada a ele próprio, desmentem essa interpretação. Vendo náo na Igreja, mas na fé a força capaz de alimentar o círculo de onde esperava o restabelecimento de uma ordem social humana no Império, então em plena decomposição social e moral, Kraus se filia ao catolicismo. Abandona-o, desiludido, em 1923.

Não se pode compreender os 15 primeiros anos da Fackel sem considerar a posição específica de Kraus no campo intelectual vienense: enquanto todas as instituiçóes oficiais o ignoravam, seu público só crescia. Na prática, a ordem oficial de silenciá-lo transformou-o, aos olhos de seus admiradores, em vítima, em herói solitário empenhado em um combate desinteressado pela verdade. Ao mesmo tempo, a esperança depositada nele e certa exaltaçáo da luta individual tornava extremamente difícil toda colaboração com produtos cuja produção ele de fato não controlasse: em 1910, Kraus encerra sua colaboraçáo ao Simplicissimus e ao März; a partir de 1912, renuncia a qualquer ajuda para publicar a Fackel. É nesse contexto que começa a elaborar a sua visão de uso "puro" da língua, da unidade 
entre forma e conteúdo entendida como última salutar maneira de escapar do caos cultural.

Dentro do ostracismo em que se encontrava, a acolhida entusiasta recebida em Berlim, em 1910, e o clima intelectual mais aberto do que em Viena encorajaram Kraus a mudar de domicílio. Contudo, ele não tardaria a tomar distância desse meio literário menos diretamente submetido às pressóes comerciais que o vienense, mas onde os apelos do aliciamento tendiam a transformar toda escrita em manifesto político:

Não tenho mais a fazer com as filiações de política literária de Berlim e de seus futuristas, seus neopatéticos, seus neoclássicos e outros detentores de títulos diversos, do que com os consultores comerciais de Viena... Não sou de opinião que opinião seja suficiente em arte... Penso que polêmicas destituídas de valor artístico pertencem ao domínio do mau gosto... Acho o manifesto dos futuristas a expressão da contestação oriunda de uma pobreza de espírito revoltada, ainda mais baixa do que a dos filisteus que contaminam a arte com a sua inteligência... Estimo e ao mesmo tempo deploro o fanatismo que não vê que este é um dos sacrifícios que ele oferece à arte. (KRAUS, 1958, p. 76-77).

O caminho escolhido por Kraus - a recusa de toda concessão ao preço do isolamento - era largamente facilitado por sua situação material. As vendas da Fackel e a bilheteria de suas conferências públicas cobriam os custos e ainda permitiam ajudar alguns artistas em situação de necessidade. Além disso, desde 1901 Karl Krauss recebia uma pensão de sua família, o que lhe permitiria levar até a morte uma vida modesta, mas ainda assim confortável se levarmos em conta a situação de miséria reinante na Áustria durante e depois da guerra.

\section{Um tempo de obrigações}

Karl Kraus viveu esses tempos "heróicos" e "decisivos" como situaçôes reveladoras e quase experimentais, que serviam para provar suas teses sobre o funcionamento do meio intelectual sob a forma mais pura, e a mais terrível também. Ele esperava o apocalipse - falava disso desde 1912 nos textos e conferências em que acusara os intelectuais de contribuírem para com ele com sua complacência. Ainda assim, o começo da guerra foi um choque, tanto que a Fackel interrompe sua tiragem por vários meses e só reaparece mais tarde, muito irregularmente. 
Em meio à mobilização nacionalista e ao entusiasmo criado e mantido artificialmente, as pressões que tinham levado os intelectuais a se adaptarem aos ares daquele tempo atingiram o seu nível máximo. Nesse processo de adaptação, Kraus não podia perdoar aos poetas a glorificação da guerra e do crime coletivo. Diante de tamanha falta para com a palavra, pela primeira vez ele justifica o silêncio:Nesses tempos em que coisas inimagináveis se passam, e onde coisas para além da imaginação ainda devem acontecer justamente porque se pudéssemos imaginá-las elas não aconteceriam; nesses tempos soturnos em que se morre de rir da possibilidade de se tornarem sérios... nesse tempo cheio de ruídos refletindo uma sinfonia trágica de atos que produzem reportagens, repleto de reportagens culpadas pelos atos que produzem: nesse tempo não espere nenhuma palavra de minha parte. Nenhuma, salvo a seguinte: que só o silêncio vos salva de ser mal interpretado. (DIE FACKEL, 19|4, p. I).

No momento em que os escritores enalteciam as crueldades da guerra como atos "heróicos", só o silêncio poderia salvar o que havia de puro na arte e na escrita. A exaltação nacionalista e xenófoba da "cultura alemã" só faria destruir o que ainda restava de intacto e autêntico. Pior que a prostituição dos escritores durante os tempos de paz, pior que a corrupção miúda para avançar na carreira, o uso interesseiro da linguagem em plena guerra era percebido por Kraus como o mal absoluto, imperdoável, um verdadeiro pecado. Os culpados não mais poderiam esperar pela sua benevolência, mesmo passados anos da guerra. De fato, a guerra tinha aberto novos campos de ação para os intelectuais, tanto nos órgãos de propaganda ("o quarteirâo de imprensa de guerra") quanto nas coberturas jornalísticas em reportagens "vivazes" do front. Entre todos os fenômenos monstruosos produzidos pela guerra no meio literário, aquele da "reportagem de front" era o pior, a mentira das mentiras. O fato de uma mulher, Alice Schalke, da Neue Freie Presse, ter se tornado a vedete desse tipo de jornalismo era mais uma ilustração caricatural do nível de perversão de que a empresa cultural tinha se tornado capaz. Muitos escritores percebiam essa falta ética apenas como um preço a pagar para escapar da mobilização forçada e do envio aos campos de batalha. A esse respeito, Kraus escreveu: "O serviço de guerra voluntário dos poetas é sua entrada no jornalismo" (DIE FACKEL, 1914, p. 16). Muitos amigos de Kraus tiveram que partir para a guerra, vários deles morreram. Georg Trakl, poeta da sua mais alta estima, se suicidou em 1914. "Os melhores se vão e os piores ficam. Estes não têm que morrer. Eles sabem escrever.” (KRAUS, 1959, p. 22). 
Para evitar a censura, Kraus se contentava com fazer as frases dos outros falarem, reunindo-as numa colagem de textos retirados principalmente de jornais, acompanhadas de um curto comentário. Deixar falar a fraseologia - a exemplo da apresentação dos cemitérios de soldados como uma futura atração turística benéfica à economia local - era suficiente para desmascarar, sem ter que enunciar uma opinião própria.

Nunca, nem o mais duro lápis vermelho do censor poderá penetrar o fundo de meu ser. Renunciando à liberdade de uma opinião, não quero mais do que conceder a palavra às coisas. (DIE FACKEL, 1916, p. 128). ${ }^{20}$

Testemunho desse tempo, sua peça monumental com doze horas de duração Die letzten Tage der Menschheit (As Últimas Jornadas da Humanidade) se limita a reproduzir cenas da vida cotidiana, muitas das quais extraídas do meio intelectual e literário a serviço da guerra. Para além da visão crítica e pessimista sobre os intelectuais, a guerra reforçava o pessimismo de Kraus em relação ao "progresso" e aos benefícios da técnica, que havia tornado possíveis os morticínios em massa sem que o assassino sequer pudesse imaginar ou simplesmente registrar concretamente os seus atos. O final da peça ostenta esse pessimismo generalizado: a derrota da Áustria é apresentada como a derrota da humanidade. Os humanos saúdam uma chuva de meteoros capaz de destruir o mundo inteiro como uma nova arma miraculosa de vingança. No silêncio final, escuta-se a voz de Deus: "Foi sem querer".

A despeito do seu irredutível pessimismo, depois da guerra Karl Kraus se engaja com todo o empenho ao lado dos únicos que poderia ter em conta como não responsáveis pelas desgraças do passado. A social-democracia era a única força política do país disposta a levar a responsabilidade de guerra das potências centrais (a Áustria-Hungria e a Alemanha) às últimas consequências. Tal como ela, Kraus saudava a derrota como um purgatório necessário, mas não deixava de denunciar os termos dos contratos de paz impostos pelos vencedores. Tais contratos, na sua opinião, além de inviabilizarem qualquer reflexão crítica sobre as razóes da guerra, ainda serviam para reforçar os desejos de vingança militar.

20 Nie wird bis auf den Grund meiner Erscheinung der kühnste Rotstift eines Zensors dringen. Verzichten auf die Freiheit einer Meinung, will ich die Dinge nur zur Sprache bringen. (DIE FACKEL, 1916, p. 128). 
Em 1919, Kraus publica um apelo eleitoral em favor da social-democracia no programa de uma de suas conferências públicas. Também reconhece o equívoco de ter acreditado ser possível alguma renovação partir do pensamento conservador. Em 1923, quando se torna evidente que a Igreja interviria com toda a força para impedir a social-democracia de exercer o poder (alçando um padre à cabeça do Partido Social Cristão, Ignaz Seidel, mais tarde empossado Chanceler da Áustria), Kraus abandona a Igreja.

Outro fator que tendia a reforçar os laços de Kraus com o partido socialista era a mudança ocasionada no meio literário pela conjuntura política dos primeiros anos do pós-guerra. Enquanto nas grandes cidades (ou seja, Viena) certa intelligentsia festejava o advento da revolução e transformava a literatura em manifesto político, nas províncias dominadas pelas forças reacionárias, as universidades continuavam a distribuir títulos de doutor honoris causa aos poetas de guerra, que clamavam por vingança.

Quando em 1920 Kraus dá uma conferência pública em Innsbruck, a imprensa local e os estudantes nacionalistas e católicos pedem à populaçáo que «[...] cace esse judeu traidor que náo tem o direito de querer impor exigências éticas ao povo alemáo.” (PFABIGAN, 1976, p. 209). No revolucionarismo literário, Kraus via a réplica invertida do poeta que às vésperas da guerra oferecera seus serviços à exaltação do sentimento nacional e patriótico. Na sua dedicação às causas nobres, essas duas espécies de escritores tinham em comum renunciar ao controle do que diziam e à responsabilidade de intelectual.

\section{A quem interessa e para que servem os manifestos intelectuais}

Um pequeno episódio na controvérsia que opóe Kraus ao revolucionarismo literário ilustra particularmente bem sua tática de sociologia-ação.

Com o objetivo de desmascarar o oportunismo intelectual, Kraus envia duas falsas petições aos jornais. Metade dos "signatários" desses abaixo-assinados era composta por intelectuais honestos, que durante a guerra náo tinham sucumbido à tentação do nacionalismo; a outra metade era de intelectuais que naquele período trabalharam para a propaganda de governo. 
Como numa experiência de laboratório, a prevalência do oportunismo em um dos grupos - sendo um deles tratado como grupo experimental, outro como grupo controle - foi testada a partir da reação de cada integrante à usurpação de sua assinatura.

Bem antes de Ernst Toller ser acusado em Munique, uma moção de intelectuais vienenses foi enviada sem indicação do remetente aos jornais muniquenses para protestar contra a execução do escritor. Entre os nomes que apareciam no documento, alguns declararam jamais tê-lo assinado. Hermann Bahr declarou que seu nome foi usado sem seu conhecimento, mas com seu consentimento. Pouco mais tarde, acrescentou que "[...] protestava contra o uso de seu nome sem prévia autorização". Enquanto a imprensa de Viena ainda repercutia a estupefação geral causada pela falsa petição, outra, assinada por Blei, Ehrenstein, Moissi, Gütersloh, Roland, Sonnenschein, Werfel, era publicada nos grandes jornais liberais Neue Freie Presse e Neue Wiener Tagblatt sem suscitar nenhuma surpresa nem comentário. Os "signatários" dessa última moção declaravam não ter assinado o primeiro manifesto, mas estarem gratos por toda e qualquer contestação ao terror:

Somos gratos ao assinante anônimo por ter obsequiosamente protestado contra a execução de Toller antes mesmo de lhe ser dirigida a acusação, e de ter acrescentado ao documento as nossas assinaturas. Por esse ato pouco escrupuloso ele nos dispensou de nosso dever humanitário. Daqui por diante, não queremos mais perder nenhuma oportunidade proporcionada aos ainda vivos de se reunirem em torno de um protesto fraternal mundial numa época marcada pela avalanche de condenações à morte. Esse protesto deverá ser também uma reprovação à vingança mortífera da burguesia que ameaça futuras vítimas bem conhecidas, afora a vingança que a ditadura de conselheiros já tem infligido a vítimas inocentes. (DIE FACKEL, 1919, p. 2).

Ao final do manifesto, os "signatários" explicavam o seu próprio silêncio a respeito dos crimes de guerra:

[...] o ensejo para assegurar que nossos protestos contra milhões de mortos e de execuções de seres inocentes entre o começo da guerra e a derrota das monarquias centrais (Alemanha, Austria-Hungria) não puderam ser feitos em voz alta por uma única razão: na situação de guerra, impunha-se o silêncio... e nós estávamos todos em posições que teríamos de abandonar, sem outra perspectiva que a de colocar em perigo nossa própria integridade física. Se durante esse período um anônimo corajoso tivesse usado como hoje a nossa assinatura para protestar contra a violência da guerra, teríamos sido forçados a desmenti-lo. (DIE FACKEL, 1919, p. 2). 
Só o Arbeiter Zeitung, jornal oficial do Partido Social-Democrata, compreendeu imediatamente a importância desse affaire e saudou o responsável pela iniciativa. $\mathrm{Na}$ realidade, Kraus conseguira prever com exatidão as reaçóes dos "signatários": os que no passado náo tinham assumido algum comportamento intelectual excessivamente oportunista iriam simplesmente reprovar o uso não autorizado de sua assinatura, independente de, política e intelectualmente, estarem posicionados relativamente próximos de Toller: tratava-se dos escritores Seitz, Bauer, Friedrich Adler, e os não corrompidos Tandler, Schnitzler, Behr-Hofmann, Hofmannsthal, Zweig. Os que não desautorizaram o uso de seu nome no primeiro manifesto foram todos escritores que, de uma forma ou de outra, colaboraram com a propaganda de guerra, e depois dela, durante os meses de agitação revolucionária, passaram a adotar posiçóes radicais de "esquerda".

Com esse golpe, Kraus conseguiu demonstrar duas coisas. Primeiro, a reação da imprensa e a forma com que ela acolheu a segunda petição denotam que os jornais liberais consideravam-na um documento plausível, logo, honesto, da autoria de escritores cujo oportunismo no passado já era, de fato, aceito, na medida em que apenas refletia os compromissos que todo jornalista era levado a assumir durante os períodos de censura. Essa evidência foi imediatamente ressaltada pela imprensa social-democrata que, tendo resistido ao oportunismo durante a guerra, atacava os jornalistas "vendidos" da imprensa burguesa. A controvérsia pela imprensa, por sua vez, forçou os "signatários" da segunda petição a tomarem posição sobre as passagens do texto que faziam referência ao seu trabalho durante o conflito. A defesa deles permitiu a Kraus dar seu segundo golpe, exatamente como havia previsto. Todos esses escritores se apressaram a tirar de suas gavetas textos anti-militaristas que não puderam publicar durante a guerra; ou então se justificaram como Werfel, explicando a sua "dupla ação" de fazer o estritamente necessário como funcionário público (Werfel tinha sido correspondente de propaganda do governo da Suíça) para impedir o pior, e denunciar privadamente os crimes oficiais cometidos. Kraus não deixava de comparar com seu próprio silêncio essa defesa de uma dupla moral intelectual supostamente necessária, logo positiva, em tempos de censura. Afora isso, ele publicava longos extratos de textos daqueles escritores glorificando o despertar nacional e a guerra, o que demonstrava estarem eles 
bem distantes dos atos necessários para melhor encobrir uma opinião, ou de açôes humanitárias de resistência durante a guerra.

Esgrimindo a palavra, Kraus conseguiu desvendar os fundamentos do oportunismo intelectual. Em outras palavras, ele se deleitava em constatar que exatamente a má consciência do passado era o que tinha levado os antigos escritores de guerra a hesitarem reprovar o uso de suas assinaturas, já que aparentemente a utilização das assinaturas lhes oferecia um álibi, ou seja, credibilidade e legitimidade oportunas num campo intelectual que vinha se adaptando a um novo contexto político, temporariamente dominado pelas forças de esquerda.

\section{As contradições de um "intelectual orgânico”}

A convergência relativa de opiniáo com a social-democracia inaugura uma fase nova no trabalho de Kraus. Depois de ter atravessado a guerra em estado de solidão intelectual, essa relação com o partido abriu para ele um público maior que o círculo de intelectuais fiéis. A organização cultural do Partido Social-Democrata (Sozialdemokratische Kunststelle) ${ }^{21}$ montou vários ciclos de conferências com Kraus. Além disso, reservou-lhe a honra de ser, por muitos anos, o orador principal convidado nas festas de aniversário da República. Sob muitos aspectos, os esforços da Kunststelle coincidiam com seu ideal de renovação cultural: no âmbito da formação continuada do partido ela costumava convidar, além do próprio Kraus, os membros do círculo filosófico de Viena para fazer conferências e Alban Berg para lecionar cursos de música.

Durante alguns anos esse papel destacado, assim como as honras que o partido dispensou a Kraus fizeram com que parecesse um intelectual de partido. Essa impressão também era reforçada pelo silêncio que as instâncias culturais oficiais da Áustria reservavam a ele, chegando mesmo a manter sua hostilidade intacta numa altura em que Kraus já havia adquirido certa notoriedade no estrangeiro, como atesta o convite da Sorbonne em 1923 para uma série de conferências em alemão e sua indicação para o Prêmio Nobel de Literatura em 1926, por iniciativa de intelectuais franceses

2I Para as atividades da "Sozialdemokratische Kunststelle", ver: WEDENHOLZER (1978, p. 48I SS). 
(SHICK, 1965, p. 119). Mas em nenhum momento da sua relação com a social-democracia Kraus aceitou realmente desempenhar o papel de intelectual aparelhado. $\mathrm{Na}$ resposta que enviou aos votos do presidente da República, o social-democrata Karl Seitz, por ocasião do vigésimo aniversário da Fackel, em 1919, já se podia antever conflitos futuros. Seitz havia escrito: "Cada republicano deve reconhecer que com sua palavra você contribuiu para caçar velhos demônios...” Ao que Kraus respondeu: "Guarda aos demônios que se crê terem sido caçados, mas que ainda estão entre nós. Enquanto houver jornalistas, os demônios permanecerão entre nós...”. 22

As desavenças surgiam lá onde o partido, por razóes táticas ou por simples insuficiência de poder, não conduzia bem as reformas ou não se engajava nas lutas que pareciam cruciais a Karl Kraus. Uma dessas reformas dizia respeito aos jornais. Viu-se que os jornais austríacos não distinguiam as matérias informativas das publicitárias. As páginas políticas e econômicas eram quase sempre uma soma de artigos pagos para influenciar o jogo político ou a bolsa de valores. Depois da guerra, uma nova lei deveria pôr fim a tais práticas de manipulação. Mas, sob a pressão dos partidos de direita e mais preocupado em fazer passar uma legislaçáo social, o partido socialista aceitou uma reforma extremamente limitada, que obrigava a diferenciar textos de anúncios sem necessariamente ter que precisar essas modalidades. Assim a Neue Freie Presse limitou-se a inserir, por apenas um dia, uma curta nota de algumas linhas declarando que dali por diante todos os artigos pagos levariam a marca de uma pequena cruz ao final do texto (PFABIGAN, 1976).

\section{O caso Bekessy e a ruptura com o partido}

A inflação e a crise do pós-guerra deram origem a uma nova imprensa sensacionalista, que não se deixava inibir pelas razóes de bom tom e bom gosto respeitadas nos jornais tradicionais, e cuja tiragem rapidamente ultrapassou a desses últimos. O imigrante húngaro Imre Bekessy foi uma figura emblemática desse jornalismo nascido da inflação e da acumulação de novas riquezas. Foi em Budapeste que ele começou a praticar o seu

22 Ver: o artigo Die Gespenster, Die Fackel, p. 49 ss, 1919. 
jornalismo de chantagem. Lá, incialmente fez campanha em tom de esquerda contra as novas fortunas, mas pouco mais tarde aceitou o dinheiro dos novos ricos para combater os revolucionários em seus jornais. Quando Bela Kun assumiu o governo, Bekessy se tornou logo um de seus propagandistas e preparou a primeira edição a preços populares das obras de Marx em húngaro. Depois de fugir de Viena, tratou de estabelecer contato com as novas autoridades do almirante Horthy e de desenvolver um jornalismo similar na Áustria. Em seu jornal Die Stunde (A Hora) e nas revistas Börse (Bolsa) e Bühne (Cena) atacava as grandes fortunas acumuladas durante a época da inflação. Em troca de vultosas somas em dinheiro ele suspendia suas revelaçóes. Em geral, conduzia essas chantagens sem peia nem disfarce. Bekessy, que era puro produto da guerra e da inflação, se vangloriava da honestidade e de seu cinismo:

Meu temperamento, minha situação e minha atitude em relação à vida me fazem pender para a venalidade, e seguindo essa linha, os jornais que crio e sustento parecem estar cheios de contradições. São marcados por um homem que compreende as atividades do mundo capitalista e que deseja desmascarar essas atividades sem se tornar nem revolucionário nem asceta. Sou incapaz de mascarar essa contradição pela hipocrisia. (FIELD, 1967, p. 157).

Não era fácil para Kraus desmascarar esse jornalista vaidoso de suas atividades duvidosas. Por isso o conflito com Bekessy tomou inicialmente formas indiretas. Kraus criticava as práticas fraudulentas e chantagistas de Bekessy; este lhe respondia por intermédio dos críticos literários de seus jornais, tomando partido de todos os adversários de Kraus nas contendas literárias. Além disso, os jornais de Bekessy tentavam ridicularizar Kraus taxando seus ataques na Fackel de inveja de baixo nível, ou ainda de vaidade ou narcisismo de criança mimada e sustentada no luxo pela família. Esses artigos costumavam atribuir a Kraus uma imagem confusa de querelante, e culminavam com a questão: "O que ele quer?” Ao que Kraus responde: "Que esse ordinário deixe Viena!” (DIE FACKEL, 1925, p. 145 ss).

Em um número da Fackel, Kraus dá maior precisão às suas acusaçôes; enumera 15 processos judiciais húngaros entre 1912 e 1921 relativos aos delitos de chantagem, de roubo, incitação ao suicídio, usura e difamação praticados por Bekessy. E, como no caso Bahr, Kraus sugere a Bekessy, que o acusara de difamaçáo, de entrar com uma queixa caso suas acusaçóes 
não fossem verdadeiras: «Para evitar a repetição das minhas difamações, o senhor Bekessy não tem necessidade de uma nova lei. Basta recorrer ao parágrafo existente contra as difamaçóes." (DIE FACKEL,1925, p. 158).

Para facilitar a formulação da queixa, Kraus explicita as acusaçóes em três pontos objetivos.

I. Desde sempre Imre Bekessy é um ser sem nenhum pudor político nem caráter;

2. Imre Bekessy é um mentiroso e um fraudador. Difunde todo tipo de informação falsa e inventada para satisfazer seus sentimentos de vingança pessoal ou sua vontade de enriquecer;

3. Imre Bekessy é um jornalista venal. Pede e aceita propina em troca da divulgação de matérias elogiosas e de artigos que fazem subir ações na bolsa, com o objetivo de servir aos interesses materiais e pessoais de seus clientes. (DIE FACKEL,1925, p. 170).

Bekessy desconhecia o nível de precisão dos ataques. Sentindo o perigo se aproximar, tentou primeiramente reforçar suas ligaçóes com a equipe de governo, principalmente com o ministro das finanças.

Enquanto isso, Kraus preparava meticulosamente seu golpe final. Ele já vinha colecionando, com a ajuda de um advogado, uma série de provas de casos de chantagem praticados por Bekessy - que, por razóes de política, nunca tinha sido levado para diante de um tribunal. Quando, em 1926, faliu o Banco Central de Viena, cujo proprietário era um dos poderosos protetores de Bekessy, o procurador da República declarou que se fossem apresentadas provas de chantagem relativas ao caso, entraria com uma ação.

Kraus jubilava. Ninguém mais impediria a ação judicial pela qual tanto havia esperado. Em um número da Fackel intitulado "A Hora do Tribunal", ele passa em revista toda a história do processo, em particular a completa falta de apoio a sua perseguição contra Bekessy. Essa ausência tornava-se compreensível levando-se em conta que Bekessy conseguira acumular informação suficiente para chantagear lideranças e dirigentes de todos os espectros políticos, além das grandes organizaçôes do mundo industrial e bancário:

Há não muito tempo, elogiavam meu talento de "delegado de polícia". Reconheço que nesse caso de luta contra a indignidade, propriamente dita, não desdenharia do título de 
grande inquisidor. [...] O que eu quero efetivamente é libertar uma região cultural do banditismo jornalístico que se alçou às instâncias mais representativas dessa profissão. Sou, sim, um detetive, um comissário pronto a me estabelecer enquanto corpo policial para dar assistência, se não mesmo substituir o aparato de Estado; e nessa situação não me repugna ter que recorrer às fontes brutas mais baixas da minha produção, o que se chama "material de trabalho"; não temo nem mesmo ser reprovado pelo uso de "alusões". (DIE FACKEL, 1926, p. 20-21).

Ainda nesse artigo, Kraus advertiu o mundo político da existência de pressóes sobre o poder judiciário, com o objetivo de tornar possível o impossível: absolver Bekessy.

Ele talvez acredite poder convencer o mundo e a si mesmo de que, depois de corromper a política, ele poderá transformar a justiça numa prostituta comum... Que ninguém tente parar o processo! Que nenhum político ouse erguer uma mão protetora em favor da imprensa Bekessy, se não quiser correr o risco de se tornar suspeito de ter tesouros escondidos ali. Aquele que favorece o acusado nesse caso logo se tornará culpado de colaboração e de fraude. (DIE FACKEL, 1926, p. 15, 27).

Uma vez conhecida a abundância de provas, e, sobretudo, depois de as autoridades húngaras aceitarem disponibilizar para a justiça austríaca os documentos que revelavam as atividades de Bekessy em Budapest antes de 1920, o acusado fugiria primeiro para Paris e mais tarde para a Hungria e os Estados Unidos.

Kraus considerou a fuga de Bekessy como a sua maior vitória, solitariamente conquistada. A ação do partido socialista nessa controvérsia foi para ele uma grande decepçáo e, finalmente, o começo da ruptura com o partido, em 1930. Tanto a imprensa partidária quanto a imprensa burguesa, que estavam diretamente sob influência de Bekessy ou de algum dos seus amigos, só fizeram campanha contra ele quando o resultado do conflito já era previsível. A razão dessa hesitação foi o papel mediador desempenhado por Bekessy na venda de uma empresa cooperativa de panificação (Hammer Brot Werke) a um banqueiro. A panificadora fazia parte de uma rede de cooperativas ligadas ao partido socialista, que desejava a venda devido à má gestão e aos casos de corrupção identificados na direção.

Por conta disso, as relaçóes entre Kraus e o partido se deterioraram mais e mais, com uma única remissão por ocasião dos acontecimentos 
sangrentos de 1927. Naquela ocasião, uma multidão protestou diante do Palácio da Justiça em Viena contra a absolvição de dois membros das milícias fascistas (Heimwehren) ligados ao Partido Social Cristão, que mataram um idoso e uma criança presentes em uma manifestação. A clemência dos juízes mostrava a verdadeira face e a parcialidade da justiça, que infligira duras penas aos socialistas, acusados de perturbação da ordem pública. No confronto com a polícia, um grupo de manifestantes ateou fogo no Palácio da Justiça. Diante do agravamento da situação, o chefe da polícia vienense, Johannes Schober, deu ordem para atirar, e 89 manifestantes foram mortos. Na Fackel, Kraus apresenta uma colagem de artigos, manchetes e reaçóes de repúdio ao acontecimento, publicados em diferentes jornais, para demonstrar o quanto a República se encontrava em perigo.

O título dado a esse número da Fackel repetia as palavras com que o chanceler Seipel agradecera a Schober pela ação da polícia: "A rocha da República" (DIE FACKEL, 1927). Kraus ironizava a exaltação que a imprensa burguesa fazia da clarividência do chefe de polícia, de seu sangue-frio e de sua ação controlada sobre os transeuntes que testemunharam o fato, e igualmente sobre os familiares das vítimas. Além das suas supostas qualidades, Kraus reprovava a discreta ajuda que o chefe de polícia dera a Bekessy, permitindo-lhe a fuga de Viena, a despeito de ter contra si uma ordem de prisão. Com tal revelação, Kraus queria de novo usar a instrução do processo como meio e ferramenta de demonstração, dessa vez contra Schober. Desafiou-o publicamente a pedir demissão, mas sem sucesso; pouco depois, o Partido Social-Democrata desistiu de levar a ação adiante.

De fato, os acontecimentos de 1927 foram pontos culminantes ${ }^{23}$ na crescente militarização da vida pública austríaca. De um lado, havia os sociais cristãos e o Chanceler Seipel tentando construir um bloco antimarxista e impedir por todos os meios os sociais-democratas de chegarem ao poder. No campo adversário estava o Partido Social-Democrata, eleitoralmente o mais forte, mas que, sem dispor de maioria absoluta no parlamento,

23 A história da Primeira República austríaca se caracteriza pelo alto nível de tensão política, um grande número de greves extremamente dificeis e de assassinatos resultantes da militarização de campos adversários. Somente alguns poucos anos de razoável estabilidade econômica (1924-1926) foram relativamente calmos (BOTZ, 1976). 
ficava isolado. Os dois campos tinham milícias armadas (do lado da direita, os Heimwehren, do lado socialista, o Republikanischer Schutzbund). Desde 1927 as forças militantes de direita, os Heimwehren, pressionavam pela instauraçáo de um regime copiado do fascismo italiano. Ao mesmo tempo, a coalizão parlamentar governamental composta pelos sociais-cristáos, os Heimwehren e o Partido Pangermânico (herdeiro do liberalismo tradicional) era bastante frágil. Submetida a conflitos ideológicos permanentes, ao final do regime parlamentar ela só tinha um único voto de vantagem sobre a oposição social-democrata. A oposição socialista, por sua vez, estava dividida quanto à tática a adotar diante dessa situação. Em 1926, o partido havia decidido mobilizar suas milícias no caso de um golpe fascista. Por outro lado, a ala direita do partido considerava que o ingresso em uma coalização governamental de sociais-cristãos moderados era o único meio de impedir uma guerra civil. Desse dilema resultou uma combinação política de discurso revolucionário com diplomacia de bastidores, que tinha por bem controlar os movimentos das diversas correntes de direita. Nesse jogo, Johanes Schober, um dos lideres do partido pangermânico, era uma peça-chave. De tradição anticlerical e nutrindo simpatias por somente uma parte das milícias fascistas católicas, as instâncias dirigentes socialistas pensavam ter em Schober uma pessoa capaz de impedir a hegemonia das Heimwehren no interior da direita; logo, do fascismo na Áustria. Por isso o partido se opôs apenas verbalmente a sua nomeação ao posto de chanceler em 1929. Efetivamente, em 1930 Schober reprimiu uma tentativa de golpe de Estado provinda de algumas facçóes dos Heimwehren. A ação custou a ele o posto de chanceler.

Kraus não compreendia as manobras dessa política bizantina, prenúncio do fim da República. Ao levar sua ruptura com o partido às últimas consequências, ele fez dos altos funcionários do partido o alvo preferencial das suas críticas. Na peça Die Unüberwindlichen descreveu o meio dirigente da República como um bando de proxenetas e criminosos, cuja estabilidade no poder devia-se a vantagens recíprocas. $\mathrm{O}$ sucesso dessa peça em Berlim, o isolamento de Kraus outra vez aumentando em Viena, e a simpatia artística que o ligava a Bertolt Brecht (que encenara em Berlim trechos de Die letzten Tage der Menschheit) mostram-no, uma vez mais, 
atraído pela vida cultural berlinense. Mas a escalada do fascismo na Alemanha logo suspende qualquer ideia de uma eventual partida sua para lá.

Depois de incialmente atacar a social-democracia pela esquerda e criticar seu oportunismo, Kraus decide finalmente apoiar o Chanceler Dollfuss pela seguinte razáo: via nele um dos únicos políticos austríacos a ter compreendido que naquele momento o principal perigo provinha do nacional-socialismo e do expansionismo alemão. Kraus continuará a apoiá-lo apesar da guerra civil e da instauração de um regime fascista na Áustria. Nos seus ensaios políticos, fará, inclusive, da vítima, a primeira responsável pela situação ao reprovar o jogo tático da social-democracia.

No último número da Fackel ele faz uma análise crítica minuciosa da estratégia social-democrata austríaca. Ataca sua política diplomática de corredores e meias-medidas. Atribui à direção do partido toda a responsabilidade pela derrota do projeto de renovaçáo subsequente à primeira guerra mundial, e condena nos dirigentes a cegueira de situar a luta contra Dollfuss no mesmo patamar que a luta contra o nazismo. Denuncia, em particular, a política da direção do partido emigrada a Brno, na Tchecoslováquia, que mantinha o dogma da unificação da Áustria com a Alemanha como condição do socialismo alemáo numa época em que outro não seria seu efeito senão o abandono do país à barbárie mais atroz.

A manutenção de certos dogmas parecia aos intelectuais do partido a única forma de ofuscar sua derrota histórica - tragicamente confirmada, no entanto, pela clandestinidade e pela emigração. A ilusão de um futuro próximo revolucionário, que esses intelectuais insistiam em cultivar, indicava a Kraus que a renúncia ao pensamento crítico independente tornara impossível qualquer reflexão renovadora amparada no reconhecimento dos erros do passado. Mas, tanto quanto a fé depositada por Kraus antes da Primeira Guerra Mundial nos círculos conservadores elitistas, tidos por ele como o último bastiâo contra a catástrofe inevitável, a esperança acalentada em relação a Dollfuss parece hoje uma ilusão, se não uma ingenuidade. Kraus tinha razão em criticar as forças políticas austríacas, inclusive a social-democracia, por não terem identificado a tempo o verdadeiro perigo, antolhadas que estavam pelas oposiçóes e clivagens tradicionais do campo político austríaco, no qual os nazis não desempenhavam praticamente ne- 
nhum papel até 1932. Mas errou ao tomar Dollfuss por representante de uma força política capaz de defender a independência da Áustria. Dollfuss, que os austríacos apelidavam Milli-Metternich, beneficiava-se do apoio de uma composição internacional da qual tomaram parte os fascistas italianos e húngaros, os quais lhe haviam assegurado proteção contra a Alemanha, composição que só perduraria até 1936.

Os julgamentos de Kraus sobre Dollfuss e a social-democracia são, além disso, os únicos casos em que alguma divergência de opinióes aparece na correspondência, habitualmente desprovida de qualquer referência política, entre ele e Sidonie Nadherny ${ }^{24}$, sua fiel amiga, que na Tchecoslováquia vinha se confrontando com os emigrados social-democratas. Deve-se pelo menos fazer justiça aos posicionamentos políticos de Kraus nesse período: mesmo colocando-se a favor de Dollfuss - defensor, segundo ele, da independência austríaca contra a barbárie nazi - ele não negava a opressão reinante no país. Mas ao compará-la com o que ao mesmo tempo vinha se passando na Alemanha, Kraus fazia pela primeira vez o que até então sempre se recusara a fazer: escolher o mal menor.

\section{A virtude do silêncio}

Os primeiros meses do poder nazi na Alemanha justificaram todas as visões de terror que há muito Kraus vinha tendo. Um volumoso caderno da Fackel, preparado para impressão em 1933, só pôde ser publicado em 1953: Die Dritte Walpurgisnacht. Krauss justifica essa decisão por seu receio de que os donos da Alemanha encontrassem nessa publicação o pretexto para uma ação punitiva exemplar. Em seu lugar aparece, em outubro de 1933, um número bastante curto, com o discurso pronunciado no enterro de Loos e um poema sobre seu silêncio, que terminava assim: "A palavra dormia quando esse mundo despertava." (DIE FACKEL,1933, p. 4). Um ano mais tarde, depois da guerra civil na Áustria, ele publica um último número da Fackel sob o título: "Por que a Fackel não aparece mais". Em mais de 300 páginas, ele denuncia os crimes nazis, em particular suas origens intelectuais e a cumplicidade de certos intelectuais.

24 Carta de 6 de fevereiro de 1934 (KRAUS, 1974, p. 653 ss). 
Krauss via no nazismo certa continuidade com o espírito da Alemanha de Guilherme II, com a única diferença de uma mudança de escala. $\mathrm{Na}$ Alemanha do Kaiser a expansão econômica sustentada pela fé no progresso técnico coexistira com a renovação do romantismo cultural, mistura perversa situada na raiz da glorificação exaltada e romântica do massacre tecnológico durante a guerra. Esse divórcio entre realidade e ideologia expresso na literatura é ainda mais pronunciado no nazismo, que liga sistematicamente o uso perverso da ciência à perversão da tradição cultural do romantismo. No cerne dessa união entre a exaltação da precisão técnica e o mito, ou, mais precisamente, da justificação pelo mito de certo uso da técnica, encontra-se o uso corrompido da língua. Esse uso "horrível" da língua é a fonte dos "atos de horror" na realidade. E os primeiros meses de império nazi mostraram bem a que ponto Kraus tinha razão. As destruiçôes públicas de livros, entre os quais se encontravam obras-primas da literatura alemá, eram justificadas pela necessidade de preservar a pureza das tradiçóes intelectuais nacionais; Oswald Spengler, grande crítico da decadência no Ocidente, saudava os nazis como salvadores; Gottfried Benn, autor e médico berlinense, via na revolução nacional o começo de uma nova era, da qual nasceria um novo homem, a "última grande invenção da raça branca". Esse tipo novo de homem, fundado na perfeição biológica, estaria simultaneamente dotado de uma força instintiva inata e de dons artísticos superiores. Benn é um dos mais ilustrativos exemplos do poder de atração exercido pelo nazismo sobre os intelectuais, e de como essa atração correspondia a certo ideal estético. Demonstrando a que ponto os intelectuais estavam novamente dispostos a cerrar fileiras ao lado do poder, os universitários foram uma das primeiras categorias profissionais da Alemanha a exprimir seu entusiasmo pelo novo regime. Quanto a Martin Heidegger, Kraus se contenta com escrever que já desde sempre o filósofo achava que um pequeno sapateiro da Boêmia compreendia melhor o sentido da vida do que um pensador alemão (KRAUS, 1952, p. 58). O jornalismo, posicionado na vanguarda das práticas intelectuais corrompidas, se encontra também no centro dessa avaliação crítica: "O nacional-socialismo não destruiu a imprensa; a imprensa produziu o nacional-socialismo" (DIE FACKEL, 1934, p. 141). Com suas colagens de textos e citaçóes, Kraus tenta destruir as linhagens de tradiçóes que os nazis costumavam 
estabelecer, na reescrita da história cultural alemá, entre Goethe, Fichte, Hegel, Nietzsche e os escritores e intelectuais oficiais do Terceiro Reich. Kraus contrasta sistematicamente o discurso com a realidade, sem deixar de notar que, no seu cinismo, o discurso nazi, diferente de todos os outros discursos políticos, reconhece e mesmo reivindica os crimes que comete. Lembra que a fraseologia nazi que se vangloria dos próprios crimes deve ser tomada ao pé da letra, tal como nessa citação de um dos dirigentes do movimento: "Não dizemos olho por olho, dente por dente. Não, nós vamos é partir a cabeça de quem nos quebrar um dente." (KRAUS, 1952, p. 122). Para além da análise que procedeu sobre as fontes culturais e intelectuais do nazismo, ou seja, sobre essa mistura descontrolada entre mito e fé na ciência e na técnica, os últimos escritos políticos de Kraus têm um valor documental crucial: os textos escritos em 1933 e 1935, largamente embasados na leitura de jornais e discursos políticos, assim como nos relatos dos primeiros emigrados, dáo provas de que desde os primeiros dias toda a crueldade do regime era previsível para quem quisesse ver e ouvir.

Tal como durante a primeira guerra mundial, o silêncio e a decisão de não publicar serviriam para pôr a reflexão a salvo. Face ao triunfo da simplificaçáo e da cegueira, impunha-se a mudez do pensamento:

Porque o que acaba de acontecer está verdadeiramente conforme o plano que quer reconduzir a humanidade a um estado anterior ao pecado original sem deixar de guardar o aparato que produziu sua degenerescência, e que deseja reconduzir o Estado, a economia e as experiências culturais a sua fórmula mais simples: aquela da destruição; e mesmo o cético que alguma vez tenha tido vontade de descansar, também ele se sabe integrado a esse milagre de simplicidade. Ele sente, sem justa razão, que o dom da submissão não é dado só aos crentes e aos convertidos. Para estes a submissão é óbvia e eles não só se tornam "todo o mundo", como acolhem cotidianamente novos recrutas: eles, eles são desejáveis, eles, como nós - a quem, segundo o Völkischer Beobachter nada escapa - aprenderam a renunciar a todas as diferenças intelectuais não apenas para admirar um tal Führer, mas para simplesmente amá-lo (DIE FACKEL, 1934, p. 158-159).

No momento de sua morte, em 1936, Kraus estava ainda mais isolado do que antes da Primeira Guerra Mundial. Assim como no tempo da guerra, seu elitismo havia se reforçado. Kraus sistematicamente se recusava a responder às cartas endereçadas à Fackel e pedia explicitamente a seus leitores para não escreverem mais. Seu elitismo crescente, que ia de par com a 
marginalização no campo intelectual, ficou marcado em frases pronunciadas por ocasião de uma conferência pública em 1932: "A questão de saber por que eu sou contra tal ou qual fenômeno, eu respondo: exatamente por causa desses fenômenos... Sou contra George porque ele faz versos ruins; sou contra a guerra por causa da guerra; contra a imprensa por causa da imprensa; contra a social-democracia por causa dela mesma; e contra os meus fấs por causa de suas perguntas estúpidas.” (SCHICK, 1965, p. 127).

Karl Kraus desempenhou continuamente o papel de crítico das regras do jogo intelectual. Ao transformar as situaçôes-limite do comprometimento intelectual em intervenções de sociologia-ação, ele conseguiu, melhor do que qualquer dissertação, desmascarar os mecanismos de controle e censura, assim como as relaçóes com a política e com os interesses econômicos que limitam a autonomia intelectual. Ao mesmo tempo, sua posição específica no interior do campo intelectual proveio dos mecanismos de funcionamento do próprio campo, definindo, em certa medida, suas tomadas de posição literárias e políticas.

No começo, a trajetória social de Kraus se encaixava no destino comum aos literatos-jornalistas de café da Viena do final do século XIX. Nesse sentido, seria falso definir sua posição como marginal, ou tomá-lo como elemento de validação da tese de que a marginalidade social corresponde a uma força privilegiada de criatividade e produtividade intelectual. Kraus foi arrastado para a marginalidade porque suas análises incomodavam também aqueles a quem esteve ligado em tal ou qual período da vida. A marginalidade de Kraus era menos a força do que o efeito das suas análises. De fato, ele nunca abandonou a esperança de que sua palavra impactasse a realidade, ou, em termos mais abrangentes, de que a vigilância linguística pudesse, por meio de seus efeitos de demonstração da verdade, prevenir a corrupção e as catástrofes políticas e sociais.

Mais proveitoso seria tributar o distanciamento de Kraus em relação ao meio (ao qual todas as suas características sociais o destinavam) a um fenômeno de crise do campo intelectual. Não se pode ver separadamente o fenômeno Kraus do começo do século XX e às vésperas da primeira guerra mundial. Naquele clima de complacência para com a decadência provocado pelo declínio e a declaração de guerra (sobretudo a partir das 
guerras dos Bálcãs em 1912-1913), a emergência dos círculos intelectuais e literários parecia responder a uma sede por soluçóes para a crise, acompanhada de uma completa insegurança intelectual. A vontade de clareza, à qual geralmente se alia uma necessidade estética, transformou muitos escritores em personagens proféticos. Em determinados casos, esse clima gerava estetas esotéricos; em outros, dava origem a uma literatura engajada e a uma enxurrada de manifestos político-literários.

Nesse sentido, e por analogia com a análise do campo religioso segundo Max Weber ${ }^{25}$, seria possível dizer que o papel de Kraus foi desempenhado no embalo das crises que acompanharam o processo de racionalização das atividades intelectuais - processo que se define incialmente pela substituição de um mercado intelectual pelo mecenato, e mais tarde pela extensão e estruturação desse mercado em função de demandas sociais cada vez mais específicas. E se é possível, em sociologia da religiâo, descrever a oposição entre o profeta e o corpo de sacerdotes como aquela que vai do "descontínuo ao contínuo, do extraordinário ao ordinário, do extra-cotidiano ao cotidiano, ao banal." (BOURDIEU, 1971, p. 12), pode-se, em sociologia dos intelectuais, opor o grande intelectual carismático, cuja credibilidade é função do caráter extraordinário e descontínuo de sua palavra, ao intelectual profissionalizado, cuja função é definida seja pelo serviço que ele presta a uma clientela particular, seja pelo caráter metódico e acumulativo de seu trabalho.

Com a ajuda desses instrumentos conceituais e de uma análise das transformaçóes do mercado intelectual se compreende melhor os grupos de intelectuais eleitos como alvos por Karl Kraus em diferentes momentos da carreira, assim como o grau variável de seu elitismo e isolamento social.

O primeiro grupo de intelectuais visado pela crítica de Kraus foi o dos jornalistas em via de se tornarem assalariados. O surgimento desses novos profissionais da escrita se tornou possível graças ao desenvolvimento das mídias durante o período liberal do século XIX. A mudança transformou jovens futuros escritores e/ou filósofos em manipuladores da língua e da informação a serviço de jornais controlados de perto pelo poder financeiro.

25 Vide a sistematização das análises de Max Weber por Pierre Bourdieu (I97I, p. 3-2I). 
O oportunismo intelectual foi o resultado da sujeição do trabalho intelectual, primeiramente, aos interesses materiais e simbólicos do proprietário do jornal, e a seguir às estratégias de venda do jornal.

O segundo grupo visado por Kraus, aquele dos escritores a serviço da propaganda de guerra, prefigura os profissionais de relaçóes públicas, provenientes, hoje em dia, de um apêndice das burocracias públicas e privadas.

O público cativo de Karl Kraus, e sobretudo o núcleo central desse público, era formado por intelectuais que queriam resistir àquelas tendências evolutivas do campo intelectual. Na escuta que eles faziam de alguém como Kraus, procuravam também as justificativas sociais para existirem em uma posição de recusa e de resistência, o que, por sua vez, implicava uma espécie de ascese material em relação aos lucros vinculados a posições que supostamente lhes eram oferecidas. Embora não se disponha de indicadores empíricos fortes e de meios de demonstração estatística, pode-se levantar a hipótese de que o público mais fiel de Kraus era composto por jovens estudantes e intelectuais inicialmente marcados por certo humanismo pacifista e mais tarde simpatizantes do Partido Social-Democrata.

O tom mais ou menos elitista de Kraus esteve diretamente ligado ao crescimento desse público para além do círculo mais fiel ou, pelo contrário, ao seu retraimento em direção ao núcleo restrito de devotos, sendo esse tipo de movimento também uma fonte de auto-segregação. Assim, o isolamento social e o elitismo de Kraus aumentam nos momentos em que pressóes de ordem material forçam a massa de jovens intelectuais a aceitar, solicitar, logo a contribuir para o aparecimento de posiçóes antes consideradas como corrompidas. Isso é particularmente verdade durante e logo depois da guerra, e mais uma vez durante os anos da ascensão do fascismo e do começo da crise econômica mundial que atingiria em cheio a pequena burguesia intelectual.

Ao longo desses períodos de completa redistribuição das cartas do jogo intelectual, os círculos intelectuais mais esotéricos também expressam demandas de compensação por seu sacrifício sob a forma de um pensamento elitista reconfortante. A oposição entre estética ou pura verdade versus a utilidade de um trabalho intelectual rebaixado a mercantil é frequentemente apresentada como irredutível. Ela traduz a demanda de autovalorizaçáo 
por parte de um meio intelectual que recusa os contatos com o exterior, e que geralmente vive seu retraimento de uma forma dramática, como o fim da cultura, da civilização ocidental ou, simplesmente, do mundo.

Karl Kraus não tinha como evitar se enredar na relação do intelectual carismático com seu público; no máximo ele podia tentar, bem ou mal, controlar os seus efeitos. Para se ter uma ideia da esperança que a audiência depositava nele, basta ver a comparação que os contemporâneos fizeram de suas conferências com o clima reinante no círculo de Stefan George ${ }^{26}$. Seu elitismo poderia ter-se transformado em esoterismo artístico puro, e feito de Kraus uma espécie de guru literário, tal qual George. A íntima conexão com seu público, fonte principal da energia necessária para sobreviver em um clima de hostilidade e silêncio, apresenta esse risco latente. Mas diante da escolha entre o esoterismo e a busca da verdade, Kraus definiu sua ação menos em termos de elegância de estilo do que de responsabilidade pela validade de cada palavra dita.

Foi durante o período de estabilização econômica (sempre relativa), entre 1922 e 1929, e na ausência de uma demanda por reconhecimento propriamente intelectual que o próprio Kraus, em certa medida, aceitou outra forma de profissionalização, aquela do intelectual de partido. Por oposição ao intelectual assalariado, cuja função e limites são definidos pelas forças do mercado, o intelectual aparelhado se submete voluntariamente a certas coerçóes e compromissos que ele julga aceitáveis em nome de objetivos superiores, definidos por uma organização política. No começo, a colaboração entre Kraus e o Partido Social-Democrata aparece como um chamariz para esse tipo de profissionalização, que no caso de Kraus está ligado à esperança de alargamento do seu público para além da "intelligentsia".

A polêmica que a partir de 1923 confrontou Kraus a Oskar Pollak ilustra a dificuldade de tornar compatíveis esses dois papeis do intelectual. Sob efeito das pressóes econômicas, os jornais do partido faziam concessões, aceitando anúncios de empresas denunciadas e/ou atacadas nos textos publicados, e também publicando romances sem nenhum mérito literário, apenas por desfrutarem de boa acolhida entre os leitores. Kraus atacou essa

26 Fischer (1973, p. 16, 30) compara o estilo das leituras dramáticas de Kraus às de Stefan George. 
"modernização" do jornal e viu no abandono do ideal jornalístico um dos sinais de decadência do partido. Seu posicionamento acerca dos rumos tomados pelo veículo oficial do partido, Arbeiter Zeitung (Jornal Operário), sobreveio ao conflito entre duas pessoas, cada qual representando uma concepção específica do jornalismo. Friedrich Austerlitz, redator-chefe do jornal desde a sua fundação, em 1895 até 1931, encarnava o próprio jornalismo tradicional: consciencioso e sério, ele controlava todos os textos e redigia pessoalmente a maior parte dos editoriais. Sob muitos aspectos, seu estilo de trabalho parecia com o de Karl Kraus, que ele defendeu por toda a vida. Oskar Pollak, sucessor de Austerlitz no posto de redator-chefe, em compensação, via nas concessóes ao "modernismo" jornalístico (anúncios, literatura ligeira) uma forma de preservar o número de leitores e garantir uma base econômica sólida ao jornal.

Do mesmo modo como Kraus interveio indiretamente no conflito entre eles, deplorando a guinada "comercial" do jornal, a discussão sobre o "caso Kraus" tornou-se um campo de batalha onde Austerlitz e Pollak puderam, indiretamente, expor seus pontos de vista divergentes sobre a concepçáo da Arbeiter Zeitung. Em 1923, a revista intelectual e teórica do partido, Der Kampf (A Luta) publica o primeiro de uma sequência de ataques a Kraus. Depois de denunciar o pessimismo cultural e o ceticismo em relação aos benefícios do progresso técnico e econômico, Pollak consegue nesse artigo tocar em um ponto vulnerável de Kraus: o caráter de classe do seu público. Em suma, Pollak dizia que as conferências que a Sozialdemokratische Kunststelle organizava com Karl Kraus, por exemplo, na ocasião da festa do dia da República ou do primeiro de maio, em vez de interessar ao público operário, atraiam, sobretudo, a juventude dourada vienense. Esta se deleitava ouvindo os ataques contra a Neue Freie Presse, que representava as opinióes de seus pais ${ }^{27}$. Pollak conclui com isso que um partido da importância do Partido Social-Democrata não podia seguir sustentando a qualquer preço as querelas que Kraus lançava na Fackel; ele devia submeter suas ações a outras prioridades.

27 Ver os artigos de O. Pollak: Ein Künstler un Kämpfer, Der Kampf, 16, março, p. I ss, 1923; Noch einmal Karl Kraus, Der Kampf, 19, junho, 1926. Noch einmal die Karl Kraus Anhänger, Der Kampf, 19, agosto, p. 353. 1926, bem como a defesa de Kraus por F. Austerlitz, Der wahre Karl Kraus, Der Kampf, 19, julho, p. 309, 1926. 
Analisar o papel desempenhado por Kraus como uma intervenção nos conflitos pela distribuição do poder entre diferentes categorias de intelectuais em razão das mudanças estruturais do campo permite também melhor discernir o caráter geralmente progressivo-regressivo de suas análises, que guardam em si traços de uma luta contra as tendências racionalizantes do trabalho intelectual. No limite, seria possível qualificar a escrita de Kraus de "ecologismo literário e linguístico". É assim que ele geralmente denuncia as "modernizaçóes" do campo intelectual e suas implicaçóes comprometedoras, comparando-as com um estado mais puro do passado.

Em poema escrito em 1927, Kraus caracteriza a si próprio da seguinte forma:

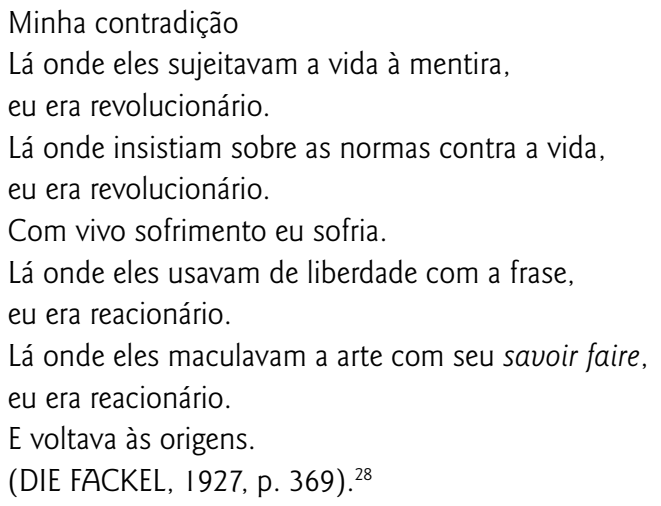

Não seria exagerado dizer que a fé mítica estabelecida por Kraus na força da palavra e de seu uso escrupuloso é, de algum modo, típica de uma época que conheceu uma série de redistribuições dramáticas das cartas do jogo intelectual, sob efeito de reestruturaçôes sucessivas das conexôes entre poder e campo intelectual. No limite, seria igualmente possível relacionar o desconforto atualmente provocado pelos textos de $\mathrm{Kraus}^{29}$, ou

28 Mein Widerspruch. Wo Leben sie der Lüge unterjochten, war ich Revolutionär. Wo gegen Natur sie auf Normen pochten, war ich Revolutionär. Mit lebendig Leidendem hab ich gelitten. Wo Freiheit sie für die Phrase nutzten, war ich Reaktionär. Wo Kunst sie mit ihrem Können beschmutzten, war ich Reaktionär. Und bin bis zum Ursprung zurückgeschritten. (DIE FACKEL, 1927, p. 369).

29 As gravações de conferências realizadas ao final dos anos de 1920 e início dos anos de 1930, recentemente reeditadas, assim como um filme realizado por um admirador e divulgado há alguns anos pela televisão austríaca, dão-nos uma boa ideia do clima reinante nas apresentações meticulosamente encenadas por Kraus. 0 
ainda pela recuperação deles para fins de desenvolvimento de uma teoria da linguagem, à resistência que ele, Kraus, opôs à racionalização do trabalho intelectual.

De fato, a vontade de sistematização, aspecto marcante nas teses acadêmicas sobre Kraus, é reflexo das regras de trabalho advindas de uma nova onda de profissionalização dos literatos, dessa vez saídos das fileiras universitárias de ciências humanas e sociais. Transformar a obra de Kraus em um discurso teórico ou político estruturado e coerente, seja por uma intenção de legitimação que leva os pesquisadores a reivindicá-lo como precursor de uma tradição política ou intelectual, seja para refutar tal tradição mediante a sua demolição, é voltar a obscurecer a importância das intervenções permanentes de sociologia-ação na sua obra. Com efeito, aquelas reconstruções não chegam a levar em conta as técnicas analíticas ativas de Kraus: tais práticas seriam consideradas escandalosas em um meio que se esforça por tudo criticar, salvo a si mesmo. Demonstrar a eficácia reveladora de uma sociologia-ação desse tipo corresponderia a novamente propor armas duvidosas para um meio excelente antes de tudo no exercício da boa consciência fundada sobre a eufemizaçáo das relaçóes que ele entretém com o poder, e também fundada sobre a rapidez com que consegue se adaptar a mudanças de poder.

\section{Referências}

BÄHR, R. Grundlagen for Karl Kraus Kritik an der Sprache im nationalsozialistischen Deutschland. Köln: Böhlau, 1977.

BOTZ, G. Gewalt in der Politik, Attentate, Zusammenstösse, Putschversuche, Unruhen in Österreich 1918-1934. München: Fink, 1976.

BOURDIEU, P. Une interprétation de la théorie de la religion selon Max Weber. Archives européennes de sociologie, XII, p. 3-21, 1971.

DIE FACKEL 5, Vien, 1899.

DIE FACKEL 9, Vien, 1899.

estilo patético e teatral da retórica de Kraus é dificilmente suportável aos ouvidos contemporâneos, acostumados a um discurso político e literário menos dramático, mais banalizado e "cotidiano" (pelo menos nos países de lingua alemã). 
DIE FACKEL 29, Vien, 1900

DIE FACKEL 48, Vien, 1900.

DIE FACKEL 250, Vien, 1908.

DIE FACKEL 404, Vien, 1914.

DIE FACKEL 437-442, Vien, 1916.

DIE FACKEL 514-518, Vien, 1919.

DIE FACKEL 697-705, Vien, 1925.

DIE FACKEL 730-731, Vien, 1926.

DIE FACKEL 766-770, Vien, 1927.

DIE FACKEL 751-756, Vien, 1927.

DIE FACKEL 898, Vien, 1933.

DIE FACKEL 890-905, Vien, 1934.

DIE FACKEL 437-442, Vien, 1916.

DIE FACKEL 514-518, Vien, 1919.

FIELD, F. The Last Days of Mankind. Karl Kraus and his Vienna. Londres: Macmillan, 1967.

FISCHER, E. Erinnerungen und Reflexionen. Reinbek: Rowohlt, 1969.

FISCHER, J.M. Kral Kraus, Studien zum 'Theater der Dischtung' un Kultur-konservatismus. Kromberg/Ts: Scriptor, 1973.

KOHN, C. Karl Kraus. Stuttgart: Metzlersche Vereinsbuchhandlung, 1966.

KRAUS, K. Die demolirte Literatur. Wien: Bauer, 1897. Die Dritte Walpurgisnacht. München: Kösel, 1952. Beim Wort genommen. München: Kösen, 1955. . Literatur und Lüge. München: Kösel, 1958. Worte in Versen. München: Kösel, 1959. Sittlichkeit und Kriminalität. Müchen-Wien: Langen-Müller, 1963. Briefe an Sidonie Nadherny von Borutin, 1913-1936. München: Kösel: 1974, vol. 1. PFABIGAN, A. Karl Kraus und der Sozialismus. Wien: Europa, 1976.

SCHEU, K.R. Karl Kraus, Zum zehnten Jahrestag des Erscheines der "Fackel”. Die Fackel, n. 277-278, 1909. 
SCHORSKE, C.E. Fin de Siècle Vienna. Politics and Culture. New York: Knopf, 1980.

SHICK, P., Karl Kraus. Reinbek: Rowohlt, 1965.

WENDENHOLZER, F. (eds.). Bewegung un klasse, Studien zur österreichischen Arbeitergeschichte. Wien: Europa, 1978.

WEDENHOLZER, J. Austromarxismus und Massenkultur. Bildungs un Kulturarbeit der SDAP in der Ersten Republik. In: BOTZ, G. HAUTMANN, H. KONRAD, H.

\section{An «Enacted Sociology» of the Intellectuals: the Struggles of Karl Kraus}

\section{Abstract}

The position Karl Kraus occupied in the Austrian intellectual field is unique in the history of the intellectuals. Rather than reconstructing Kraus's theoretical thinking, it is possible to approach him as a revelator of the the rules of the game which characterize the intellectual field. His writings invite a re-reading in terms of an "enacted sociology " which uses techniques of provocation tending to expose the mechanisms set up to disguise the relationship between intellectuals and power. By analysing Kraus's interventions it is possible to relate his struggles to phenomena of crisis in the intellectual field. Kraus's role was that of denouncing the implications of a process of rationalization of intellectual activities. This process is defined initially by the substitution of anintellectualmarket for a System of patronage, and later by the extension and structuring of the market in response to increasingly precise social demands.

Keywords: Karl Kraus. intellectuel field. doxa. "Fin-de-Siècle Vienna"

Recebido em: 30/07/2018

Aceito em: 17/09/2018 